ISSN 1411 - 0067 Jurnal Ilmu-Ilmu Pertanian Indonesia. Volume 9, No. 2, 2007, Hlm. 124 - 129

\title{
PENGGUNAAN ASAM HUMIK DALAM KULTUR TRAPPING CENDAWAN MIKORIZA ARBUSKULA DARI EKOSISTEM DENGAN SALINITAS TINGGI
}

\section{THE USE OF HUMIC ACID IN ARBUSCULAR MYCORRHIZAL FUNGI OF HIGH SALINITY ECOSYSTEM}

\author{
Delvian \\ Departemen Kehutanan Fakultas Pertanian USU \\ Jl Tri Dharma Ujung No 1 Kampus USU Padang Bulan Medan \\ delvian@usu.ac.id
}

\begin{abstract}
It has been reported that humic acid can increase plant growth and benefecial soil microbe population. A glasshouse experiment was conducted to study the effect of humic acid on growth of host plant and sporulation of arbuscular mycorrhizal fungi under salt stress in trap pot culture. Trap cultures were maintenance at various salinity levels as according to field salinity. Half of the pots received $2.5 \%$ humic acid and control treatment received no humic acid. Result of research indicate that humic acid can increase growth of host plant and mycorrhizae sporulation at all salinity levels. Acaulospora is highest its spore production followed by of Glomus and Gigaspora.
\end{abstract}

Key words: trap, arbuscular mycorrhizal fungi, humic acid, sporulation

\begin{abstract}
ABSTRAK
Beberapa penelitian melaporkan bahwa pemberian asam humik dapat meningkatkan pertumbuhan tanaman dan meningkatkan populasi mikroba tanah bermanfaat. Penelitian ini bertujuan mengetahui pengaruh asam humik terhadap pertumbuhan tanaman inang dan produksi spora cendawan mikoriza arbuskula pada media bersalinitas tinggi dalam kultur trapping. Kultur trapping dipelihara pada berbagai tingkat salinitas sesuai dengan kondisi salinitas tanah di lapangan. Pot-pot kultur dibagi berdasarkan perlakukan masing-masing yaitu $0 \%$ asam humik (kontrol) dan 2.5\% asam humik. Hasil penelitian ini menunjukkan bahwa asam humik dapat meningkatkan pertumbuhan inang dan produksi spora mikoriza pada pada semua tingkat salinitas tanah. Acaulospora adalah jenis spora cendawan mikoriza arbuskula yang paling tinggi produksi sporanya diikuti oleh jenis Glomus dan Gigaspora.
\end{abstract}

Kata kunci : trapping, cendawan mikoriza arbuskula, asam humik, produksi spora

\section{PENDAHULUAN}

Banyak cara untuk mendapatkan inokulum cendawan mikoriza arbuskula (CMA), salah satunya adalah penggunaan tanah dan akar langsung dari lapangan yang diketahui mengandung CMA (Menge, 1984; Varma and Hock, 1998). Akan tetapi kultur yang langsung dari lapangan biasanya mengandung banyak mikroorganisme yang tidak diinginkan. Oleh karena itu dianjurkan untuk memulai produksi inokulum dengan kultur trapping dengan tujuan untuk mendapatkan produksi spora yang baik dan dalam jumlah yang cukup.

Sampai saat ini belum ada koleksi inokulum CMA dari ekosistem bersalinitas tinggi. Menurut 
Juniper and Abbott (1993) salinitas dapat mempengaruhi semua tahapan perkembangan CMA, mulai dari perkecambahan spora sampai dengan pembentukan spora baru. Disamping itu salinitas juga mempengaruhi perkembangan tanaman inang yang pada akhirnya juga berpengaruh terhadap produksi spora CMA (Vilarino et al., 1992). Oleh karena itu perlu dicari teknologi yang dapat menekan pengaruh negatif salinitas terhadap pertumbuhan dan perkembangan tanaman dan CMA.

Penggunaan asam humik merupakan suatu terobosan baru dalam kultur CMA. Menurut MacCarthy et al. (1990) penggunaan asam humik tidak saja dapat meningkatkan pertumbuhan tanaman tetapi juga meningkatkan populasi mikroba tanah. Asam humik juga dapat menekan pengaruh salinitas dan ion-ion logam yang bersifat toksik. Lebih lanjut Chen and Aviad (1990) melaporkan bahwa asam humik dapat meningkatkan suplai mineral terutama N, P, K dan mikronutrien serta meningkatkan kapasitas tukar kation sehingga dapat menekan ketersediaan garam-garam dalam tanah. Atas dasar hal itu maka tujuan dari penelitian ini adalah untuk mengetahui pengaruh asam humik terhadap pertumbuhan tanaman dan produksi spora CMA pada kondisi salinitas tinggi.

\section{METODE PENELITIAN}

Penelitian ini dilaksanakan pada Januari April 2002 di Laboratorium Bioteknologi Hutan dan Lingkungan PPB IPB. Percobaan disusun dalam Rancangan Acak Lengkap (RAL) Non Faktorial dengan perlakuan pemberian asam humik yang terdiri atas: $0 \%$ asam humik (kontrol) dan $2.5 \%$ asam humik. Sampel tanah diambil dari hutan pantai Cagar Alam Leuweung Sancang, Kabupaten Garut Jawa Barat pada 10 petak contoh. Untuk pembuatan kultur CMA digunakan batuan zeolit sebagai campuran media tumbuh, Pueraria javanica sebagai tanaman inang, asam humik (HUMEGA ${ }^{\mathrm{TM}}$ 6\%) dan aquades. Untuk ekstraksi dan identifikasi spora CMA digunakan bahan berupa larutan glukosa 60\%, larutan Melzer's dan larutan PVLG.

Teknik trapping yang digunakan mengikuti metoda Brundrett et al. (1994) dengan menggunakan pot kultur terbuka. Media tanam yang digunakan berupa campuran contoh tanah sebanyak $\pm 50 \mathrm{~g}$ dan batuan zeolit sebanyak \pm $150 \mathrm{~g}$. Perlakuan asam humik (HUMEGA ${ }^{\mathrm{TM}} 6 \%$ ) diberikan dengan konsentrasi $2.5 \%$ sebanyak $20 \mathrm{~mL}$ tiap pot. Frekuensi pemberian asam humik adalah 3 x 1 minggu selama satu bulan pertama dan 1 x 1 minggu selama 1 bulan kedua.

Pemanenan kultur dilakukan setelah kultur berumur dua bulan. Selain menghitung produksi spora CMA juga dihitung berat kering tanaman inang. Teknik isolasi spora CMA dilakukan dengan metoda penyaringan bertingkat yang dilanjutkan dengan teknik sentrifugasi dan kepadatan spora dihitung setiap $30 \mathrm{~g}$ sampel.

\section{HASIL DAN PEMBAHASAN}

Pemberian asam humik dapat meningkatkan pertumbuhan $P$. javanicum dibandingkan dengan tanpa pemberian asam humik pada semua tingkatan salinitas (Gambar 1). Besarnya peningkatan pertumbuhan berkisar antara 75,4\%

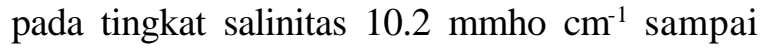

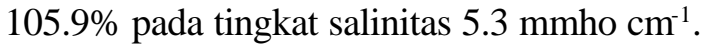

Terjadinya peningkatan pertumbuhan ini berhubungan dengan pengaruh asam humik dalam meningkatkan penyerapan hara, baik hara makro maupun mikro. lulakis and Petsas (1995) menegaskan bahwa mekanisme utama dari pengaruh asam humik terhadap peningkatan pertumbuhan tanaman adalah melalui peningkatan penyerapan hara makro dan mikro, baik melalui proses metabolik (aktif) maupun non-metabolik (pasif). Peningkatan serapan hara oleh tanaman ini juga berhubungan dengan perubahan permeabilitas membran sel akar tanaman. Chen and Schnitzer (1978) menyatakan bahwa asam humik dapat meningkatkan permeabilitas membran sel yang pada akhirnya dapat meningkatkan penyerapan hara. 


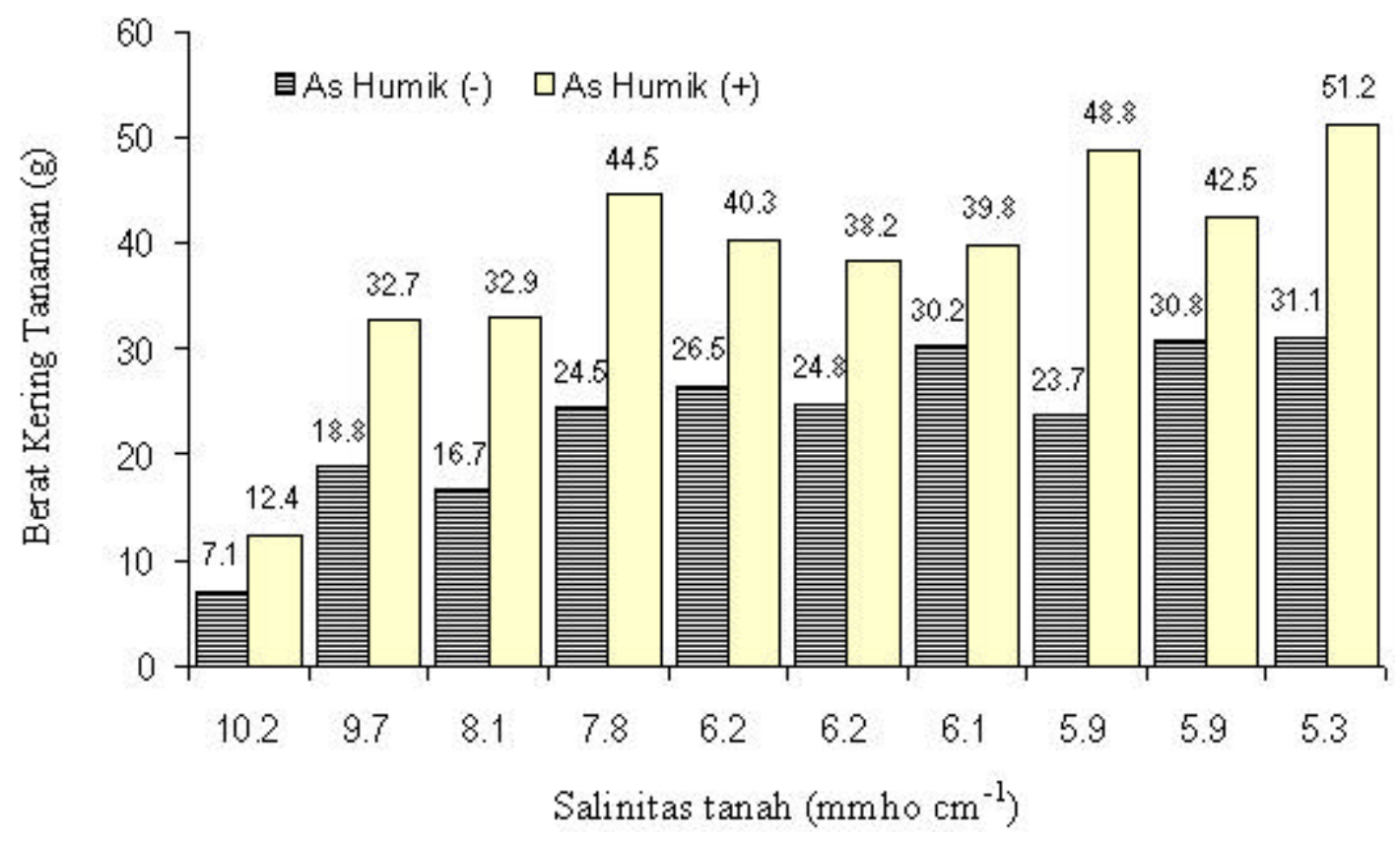

Gambar 1. Pengaruh asam humik terhadap berat kering tanaman $P$. javanicum pada beberapa tingkat salinitas tanah

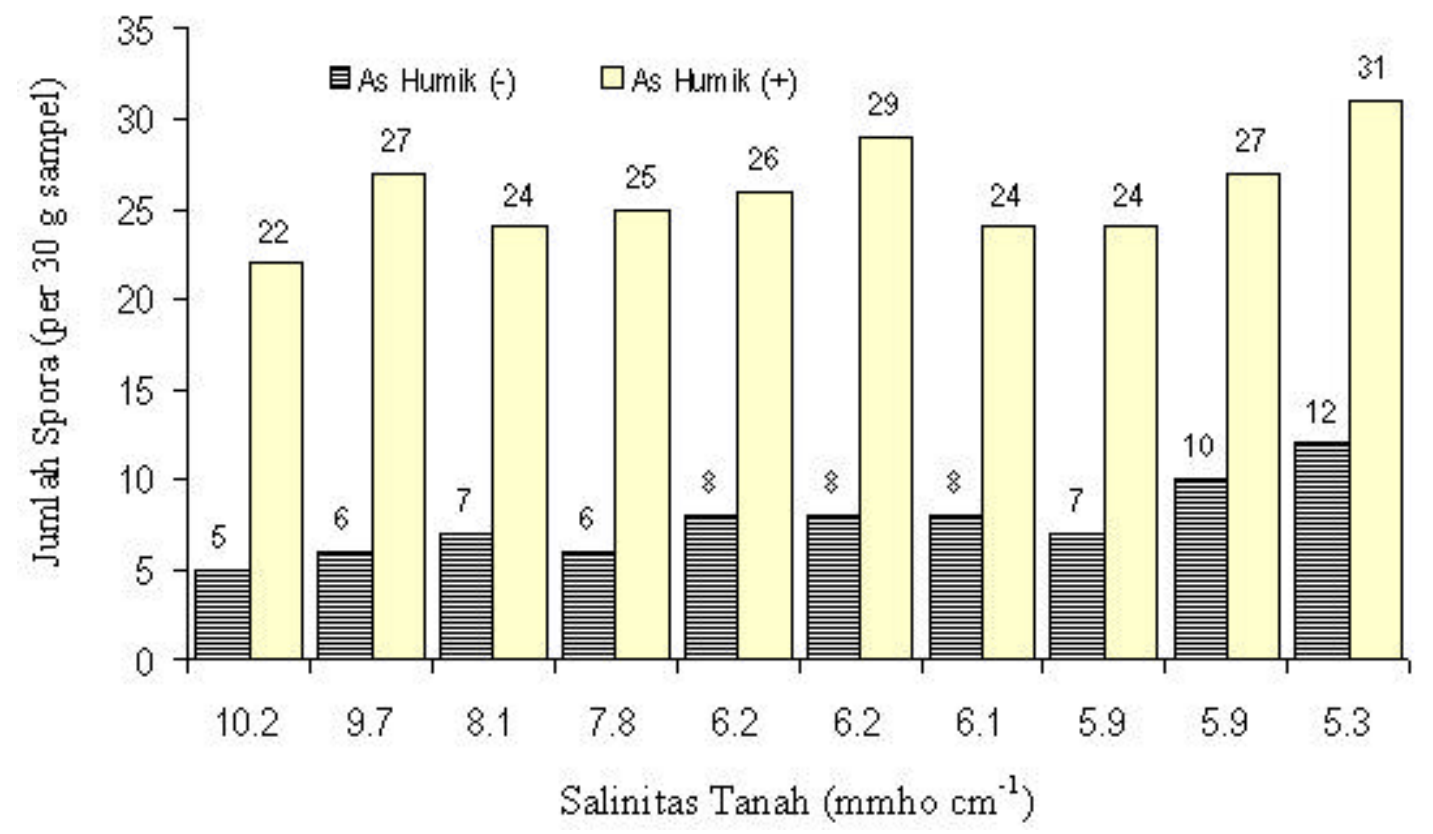

Gambar 2. Total jumlah spora yang dihasilkan sebagai respon terhadap pemberian asam humik pada beberapa tingkat salinitas tanah yang berbeda

Di samping itu pemberian asam humik dapat meningkatkan sintesis protein, aktivitas hormon tumbuh, meningkatkan laju fotosintesis, dan mempengaruhi aktivitas enzim (Chen and Aviad,
1990; Ayuso et al., 1996). Semua ini akan meningkatkan pertumbuhan tajuk, berat kering tajuk dan akar, jumlah akar-akar lateral serta dapat mempengaruhi inisiasi akar-akar baru. 
Tabel 1. Jumlah spora setiap jenis CMA yang dihasilkan sebagai respon terhadap pemberian asam humik pada beberapa tingkat salinitas tanah.

\begin{tabular}{ccccccc}
\hline \hline \multirow{2}{*}{$\begin{array}{c}\text { Salinitas tanah } \\
\text { (mmho } \mathrm{cm}^{-1} \text { ) }\end{array}$} & \multicolumn{5}{c}{ Jumlah spora CMA (per 30 g sampel) akibat pengaruh asam humik } \\
\cline { 2 - 7 } & \multicolumn{3}{c}{ Glomus spp. } & H1 & Acaulospora spp. & \multicolumn{2}{c}{ Gigaspora spp. } \\
\hline & H0 & 6 & 2 & 15 & 1 & 3 \\
\hline 10.2 & 3 & 6 & 3 & 17 & 3 & 6 \\
9.7 & 3 & 6 & 3 & 18 & 1 & 1 \\
8.1 & 4 & 7 & 3 & 17 & 0 & 3 \\
7.8 & 3 & 8 & 4 & 18 & 0 & 1 \\
6.2 & 4 & 3 & 21 & 0 & 2 \\
6.2 & 4 & 3 & 5 & 18 & 0 & 0 \\
6.1 & 3 & 3 & 3 & 19 & 0 & 2 \\
5.9 & 4 & 7 & 5 & 20 & 0 & 3 \\
5.9 & 5 & 7 & 5 & 22 & 0 & 0 \\
5.3 & 6 & 9 & & & & \\
\end{tabular}

$\mathrm{H} 0=0 \%$ asam humik (kontrol), $\mathrm{H} 1=2.5 \%$ asam humik

Pemberian asam humik juga dapat mengurangi dampak negatif dari tingginya tingkat salinitas tanah. Dengan kapasitas tukar kation yang tinggi, asam humik dapat membentuk suatu kompleks dengan ion-ion yang bersifat toksik, terutama ion-ion logam, sehingga memberikan suasana rizosfir yang kondusif bagi pertumbuhan tanaman. MacCarthy et al. (1990) menyatakan bahwa adanya asam humik dapat menekan penyerapan $\mathrm{Na}$ oleh perakaran tanaman. Sedangkan Badura (1965) menyatakan bahwa dengan kapasitas tukar kation yang tinggi asam humik dapat mempengaruhi konsentrasi dan ketersediaan garam-garam dalam tanah.

Pada kultur trapping tanpa pemberian asam humik berat kering tanaman berkisar antara 7.1$31.1 \mathrm{~g}$ tanaman $^{-1}$, sedangkan dengan pemberian asam humik berkisar antara 12.4-51.2 g $\operatorname{tanaman}^{-1}$. Rendahnya pertumbuhan $P$. javanica tanpa pemberian asam humik disebabkan dua hal, yaitu tanaman mengalami kekurangan hara dan keracunan unsur mikro terutama $\mathrm{Cl}$ dan $\mathrm{Na}$ yang berasal dari contoh tanah. Pada kultur dengan pemberian asam humik yang terjadi justru sebaliknya dimana ketersediaan hara menjadi lebih baik dengan meningkatnya kapasitas tukar kation (MacCarthy et al., 1990) dan penyerapan $\mathrm{Na}$ dapat ditekan (Chen and Aviad, 1990).

Pemberian asam humik mampu meningkat kan jumlah spora yang terbentuk (Gambar 2). Besarnya peningkatan produksi spora berkisar antara $156.25 \%$ yang terjadi pada tingkat salinitas

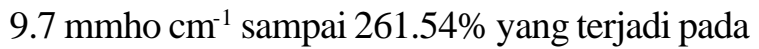

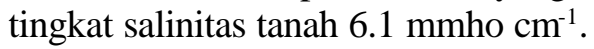

Pemberian asam humik dapat meningkatkan jumlah spora yang terbentuk. Jumlah spora yang terbentuk ini tidak terlepas dari respon pertumbuhan tanaman inang yang lebih baik dengan pemberian asam humik. Pada kondisi yang demikian prosesproses metabolisme tanaman, seperti fotosintesis, akan berlangsung secara maksimal sehingga fotosintat yang dihasilkan menjamin proses pertumbuhan tanaman dan kelangsungan simbiosis antara tanaman dan mikoriza. Dengan terjaminnya suplai karbon dari tanaman bagi perkembangan mikoriza maka sporulasi juga akan berlangsung dengan baik. Sebaliknya perkembangan mikoriza yang baik ini akan menjamin suplai air dan hara bagi pertumbuhan tanaman.

Selain daripada itu pemberian asam humik ini dapat mempengaruhi pembentukan akar-akar baru dan meningkatkan permeabilitas membran akar (http://www.horizonag.com). Banyaknya akar-akar yang baru dengan permeabilitas membran yang tinggi akan menguntungkan bagi proses kolonisasi akar oleh mikoriza. Seperti diketahui bahwa kolonisasi mikoriza umumnya terjadi pada akar-akar muda (Sieverding, 1991) dan proses kolonisasi akan lebih mudah terjadi pada akar-akar dengan permeabilitas membran yang tinggi (Cooper, 1984).

Dengan demikian jika pada satu sisi kolonisasi sudah terbentuk dengan baik dan pada sisi lain pertumbuhan tanaman juga baik, maka akan terjadi 
simbiosis yang mutualistik bagi perkembangan tanaman dan mikoriza. Salah satu ukuran perkembangan mikoriza yang lebih baik dengan pemberian asam humik ini adalah peningkatan jumlah spora yang terbentuk.

Jika dilihat pengaruh asam humik terhadap sporulasi tiap jenis CMA pada Tabel 1 tampak bahwa peningkatan jumlah spora pada semua tingkat salinitas tanah didominasi oleh jenis Acaulospora spp. Jumlah spora Acaulospora spp. jauh melebihi spora dari jenis Glomus spp. dan Gigaspora spp.

Respon pertumbuhan dan perkembangan setiap jenis CMA terhadap pemberian asam humik ini adalah variatif. Pembentuk sporaAcaulospora akibat pemberian asam humik jauh melebihi peningkatan jumlah spora dari jenis Glomus dan Gigaspora. Hal ini sangat menarik karena beberapa studi melaporkan bahwa Glomus spp. adalah jenis CMA yang paling banyak ditemukan pada tanah-tanah salin (Allen and Cunningham, 1983; Pond et al., 1984). Apakah Acaulospora lebih respon terhadap pemberian asam humik dibandingkan dengan Glomus. Tentu saja ini suatu yang memerlukan pengkajian lebih lanjut. Akan tetapi dibandingkan dengan Gigaspora jumlah spora Glomus masih jauh lebih banyak.

\section{KESIMPULAN}

Pemberian asam humik dapat meningkatkan pertumbuhan tanaman inang sehingga jumlah spora yang terbentuk juga meningkat.

Tipe spora Acaulospora lebih respon terhadap pemberian asam humik sehingga menghasilkan pembentukan spora paling tinggi yang diikuti oleh Glomus dan Gigaspora.

\section{DAFTAR PUSTAKA}

Allen, E.B. and G.L. Cunningham. 1983. Effects of vesicular-arbuscular mycorrhizae on Distichlis spicata under three salinity levels. New Phytol. 93 : 227-236.

Ayuso, M., T. Hernandez, C. Garcia, and J.A. Pascual. 1996. Stimulation of barley growth and nutrient absorption by humic substances originating from various organic materials. Bioresource Technology 57 : 251-257

Badura L. 1965. On the mechanism of stimulating influence of Na-Humate upon the process of alcoholic fermentation and multiflication of yeasts. Acta. Soc. Bot. Pol. 34 : 287-328.

Brundrett, M.C., L. Melville dan L. Peterson. 1994. Practical Methods in Mycorrhiza Research. Mycologue Publications. Ontario, Canada.

Chen, Y. and M. Schnitzer. 1978. The surface tension of aqueous solutions of soil humic substances. Soil Sci. $125: 7-15$.

Chen, Y. and T. Aviad. 1990. Effect of humic substances on plant growth. Di Dalam : maccarthy P, Clapp CE, Malcolm RL, dan Bloom PR (Eds.). Humic substances in soil and crop science: selected readings. American Society of Agronomy, Inc. Soil Science Society of America, Inc. Madison, Wisconsin, USA. p. 161-186

Cooper, K.M. 1984. Physiology of VA mycorrhizal associations. Di Dalam : Powell, C.L. dan D.J. Bagyaraj (Eds.) VA Mycorrhiza. Florida. CRC Press.

Juniper S and Abbott LK. 1993. Vesiculararbuscular mycorrhizas and soil salinity. Mycorrhiza. $4: 45-57$

Lulakis, M.D. and S.I. Petsas. 1995. Effect of humic substances from vine-canes mature compost an tomato seedling growth. Bioresource Technology 54 : 179-182

MacCarthy, P., C.E. Clapp, R.L. Malcolm, and P.R. Bloom. 1990. Humic substances in soil and crop science: selected readings. American Society of agronomy, Inc. Soil Science Society of america, Inc. Madison, Wisconsin, USA.

Menge, J.A. 1984. Inoculum production. Di Dalam : Powell, C.L. dan D.J. Bagyaraj (Eds.) VA Mycorrhiza. Florida. CRC Press. Pond, E.C., J.A. Menge and W.M. Jarrell. 1984. Improved growth of tomato in silinized soil by vesicular-arbuscular mycorrhizal fungi collected from salinie soils. Mycologia 76 : 74-84 
Sieverding, E. 1991. Vesicular-arbuscular mycorrhiza management in tropical agrosystems. Deutsche Gesellschaft fur Technische Zusammenarbeit, Germany.

Varma, A. and B. Hock. Mycorrhiza structure, function, molecular biology and biotechnology. 2nd Edition. Springer.
Vilarino, A., J. Arines and H. Schuepp. 1992. Propagule production by VA fungi in red clover plants subjected to periodic removal of the aerial parts. . Di Dalam : Read DJ, Lewis DH, Fitter AH, dan Alexander IJ. (Eds.). Mycorrhizas in ecosystems. CAB International, Cambridge. 